\title{
Why interventions in the seed systems of roots, tubers and bananas crops do not reach their full potential: a reflection based on literature and thirteen case studies
}

Authors: C.J.M. Almekinders, Steve Walsh, Kim Jacobs, Jorge Andrade, Margaret McEwan, Stef de Haan, and many more RTB collaborators (to be added)

Affiliations: Wageningen University and Research (WUR), Centro International de la Papa (CIP), Biodiversity International, Centro de Investigacion Agricola Tropical (CIAT)

Contact: Conny.Almekinders@wur.nl

Date: 12 February 2017

\section{Summary}

With RTB seed system initially not given much attention and - in very general way - in a less 'advanced stage', the awareness of their importance for food security, nutrition and income of rural households has caught up. In this publication we review the state-of-the art in relation to seed systems of root, tuber and banana (RTB) crops, with particular reference to potato, sweet potato, cassava, yam, banana, the five major vegetatively propagated food crops in developing countries. We reflect on current seed system development paradigms, and how seed systems of RTB crops feature in context, and how they differ from seed systems of "true" seed crops. Literature and 13 case studies of RTB seed system interventions are used to underpin the argument that more systematic and interdisciplinary research is needed to identify gaps in our knowledge on degeneration processes, farmer practices in multiplying in and sourcing seed. The interactions of these elements have important consequences for strategies to improve availability and access of farmers to quality seed. The evaluation of the 13 cases indicated that RTB seed system interventions are highly variable in scale and orientation. Despite the ambitious goals of the project interventions, the project implementation time was in the majority of the cases two to four year. The interventions appeared to have no links to national government policies to seed sector development, did not make specific efforts to build on existing informal seed systems and in general the efforts to learn from the experiences of the interventions seems to be meagre. Understanding farmers' effective demand for seed and how this affects the economic sustainable supply of quality seed by specialized producer-entrepreneurs is of paramount importance, regardless of the seed system paradigm, in order to be able to prioritize investments in improved use of seed by farmers. Few interventions are designed without rigorous understanding of the bottlenecks in the functioning of the existing seed system, i.e. who are the actors, what does and does not work where and for whom and why.

\section{Introduction}

Seed of agricultural crops have co-evolved with human activities. This places seeds at the nexus of many different biophysical and social dimensions that make up seed systems. Seed systems operate at different scales and involve genes, farmers, communities, researchers, politicians and governance regimes. Seed systems have an agro-ecological context as well as social and historical-political contexts, and are affected by larger global developments such as climate change, globalization of economies and demographic developments. These many different components interact and define the performance of seed systems. The ways in which seed systems are understood and the different views on how they can be improved lead to different type of interventions that are supported by different narratives that envision different pathways into the future. In this publication we look at crop-based seed systems which we consider to have two main components: a formal part and an informal part. The formal part includes research and development institutions, private sector companies and public sector 
policy and governance. The informal part refers to seed production, exchange and use by farmers, and their relation with other local actors.

Interventions into seed-systems have long been an important component of agricultural development strategies. Today, the landscape of development countries is still filled with seed system interventions: projects of different shapes and scales, aiming to enhance the adoption of improved varieties, farmers' use of seed grown off-farm or encouraging the use of practices that improve the quality of seed being planted, for different purposes, to increase seed and food security, enhance nutrition, agricultural productivity or promote pro-poor development. Although the contexts and narratives of these interventions vary, they all strive, regardless of the crop, to make quality seeds more available and accessible to farmers. There is however a general notion that these interventions often do not perform as well as our expectations (). The tremendous investments in seed system interventions and their relative lack of success can be traced back to our limited understanding of seed systems. We need a deeper understanding of how they work in order to make such interventions more effective and to up-scale the successes.

In the 1980s recognition of the importance of farmers' knowledge led to the adoption of more participatory approaches. In the field of seed and varieties this stimulated interest in informal or farmer-based seed systems (e.g. Cromwell et al, 1990, Almekinders et al., 1994) and the potential of in situ conservation and participatory plant breeding (Eyzaguirre and Iwanaga 1995, Sperling et al, 2001, Almekinders and Elings, 2001). The shortcomings of the Green Revolution led to different approaches for increasing farmers' access to adapted improved varieties and quality seed. More than two decades later, we explore the extent to which these ideas have become part of the practice in the field. We focus on cassava (Manihot esculenta), banana (Musa spp.), potato (Solanum spp), sweet potato (Ipomea batata) and yam (Dioscorea spp.): vegetatively propagated root tuber and banana (RTB) crops that play a major role in the food security of people in developing countries.

Except for potato, they are staple food crops with a historically low prestige and visibility: in most countries they received little attention from agricultural research systems until after independence from colonial rulers and the foundation of the CGIAR institutes in the 1970s. RTB crops are not only important as food crops for the poor but also have distinctive multiplication and breeding characteristics which makes their 'seed' systems different from real 'true seed' systems.

In this paper, we firstly explore the current paradigms in seed system development, and specifically how these apply to the RTB crops. We use the literature and a series of 13 case studies on seed system interventions to underpin the lessons from the last 2-3 decades on the ways that farmers' acquire quality seed, and which approaches are most effective in making these seeds available and accessible to them. The 13 case studies were identified and documented by researchers-seed experts of various CG centres with the intention of covering the range of types, scale and context of interventions in banana, cassava, yam, sweet potato and potato in Africa and Latin America (see table 1). Finally, we identify the challenges and present a cross-crop research agenda that will help to increase the effectiveness of support interventions in RTB seed systems.

Table 1. Case studies (Andrade-Piedra et al., 2016).

\section{Seed system paradigms}

\section{The current status of RTB seed systems.}

Up to the 1980s, the seed system that was promoted in developing countries was a formal public-private sector seed system model. The model originated in north-western Europe and North America where it had emerged as a result of advances in agricultural technology and a strong agricultural sector with strong lobbying power. The model recognises different stages of development and maturity and assumes that developing countries will 
follow a similar development path (Douglas, 1980, Spielman \& Smale, 2016): The actual stages vary between crops and countries, but these are all assumed to eventually develop into a final and mature stage: with a welldeveloped agricultural sector, in which commercial seed companies and the market supply most of the seed and legislation and supporting activities are functional and effective (Douglas, 1980). Seed systems of hybridized and industrial staple crops, together with horticultural crops, tend to be the most advanced. For most RTBs in the majority of developing countries the seed sector is in 'stage 1' (of the four identified by Douglas, 1980), and 'nascent' (in contrast with mature (Spielman and Smale, 2016)). Their characteristics include ineffective R \& D, a rudimentary (seed) value chain, the preponderance of farmer-saved planting material and a governance model that is largely formal and publicly managed (BMGF and USAID, 2015). Potato has a special position among the RTBs in developing countries. While an important subsistence staple for the poor in its centre of origin and other highland regions of the (sub-) tropics (the Andean region, Ethiopia, Nepal), it is a luxury crop in other developing countries, and often provides farmers with important cash income. Extensive research and regulations have been developed over time in the industrialised countries, and these have been copied and applied in developing countries. Thus, even though the potato cropping system can hardly be said to be mature in most developing countries, there is an extensive body of knowledge that can be drawn on and the seed and variety regulations of a mature potato seed system are easily copied, adapted and put in place. For the other crops there has been much less research and hardly any regulation apart from variety registration. For seed quality there are, at best, basic formulations with threshold values that are translations from sanitary health experiences in advanced seed system and market situations (check). In banana and cassava the situation can vary extremely, especially in countries with plantations for exporting banana and those with a growing cassava processing industry. For example banana tissue culture technology is strongly regulated in various countries.

\section{Productivism: the underlying technology paradigm}

The existing policy and regulation of the formal seed system reflects the pursuit of a highly productive agriculture, using intensive technology, to close the yield gap in order to be able to feed the world (Scoones and Thompson, 2011, iPES-Food 2016). The reasoning behind this approach is that farmers' choices of technology, including the choice of varieties and seed sources, are ultimately influenced by economic benefits. In the more advanced seed systems, seeds is dealt with as an external input and the farmers are market-oriented entrepreneurs within the seed value chain purchasing seed from specialized private sector seed producers (Scoones and Thompson, 2011). In other words, the market-logic organises and ensures effective production and technological development, that is geared towards maximizing yields; whilst public sector involvement is minimized to regulation and tasks that do not yield sufficient immediate benefit to be of interest to the private sector, such as upstream breeding and foundation seed production for particular cases and crops (BMFG and USAID, 2015). This view is also reflected in Africa's Green Revolution initiative in which local and/or intermediate-size private sector actors are given a prominent role (Scoones and Thompson, 2011, AGRA, 2016). This, however, poses a huge challenge for the RTB crops. The vegetative multiplication and bulkiness of the planting material makes the seed systems of these crops less attractive for private sector actors. and leave them predominantly publicly managed. This also explains why these crops are less present in investments and debates around genetically modified organisms (GMOs) and associated intellectual property rights (Tansey, 2011). Nevertheless, recent studies have indicated that there is potential for public private partnerships in RTB seed systems, in particular for the production of high quality planting material of cassava and sweet potato in the formal upstream part of the seed value chain (e.g. the production of early generation seed, EGS) although these studies do recognise that the RTB crops (excluding potato) show some tension on this point (BMGF and USAID, 2015, Lion, K., 2015).

\section{Alternative paradigms}

'Alternative' models of seed system models are predicated on the diversity of crops, contexts and farmers' needs and aspirations. They adapt a more mixed and pluralist vision of seed systems that can be of benefit to all types 
of farmers, from those with little cash to invest to those for whom agriculture is an important income generating activity. Louwaars and de Boef (2012) emphasize the multi-actor character of seed systems and promote an integrated seed system development (ISSD) model, while Thomas Sarah et al. (2015) identify the need for a more integrated seed health strategy to improve the productivity and health of potato seed systems; an approach that is also relevant for other RTB crops. These holistic approaches recognize that farmer-based and formal seed systems each have their strengths and weaknesses, that they are potentially complementary and that no single model is suitable for all crops, conditions and farmers. Consequently they advocate optimizing mixed forms of seed supply, with varying practices and flexible regulations and that R \& D for seed systems should give attention to technologies and practices that support the access and availability of quality seed from different sources for different types of farmers.

In the meantime, the farmer-based sources and flows of seed prevail in most crops in developing countries, (McGuire and Sperling, 2016) for multiple reasons (e.g. Coomes et al. 2015, Jones, 2013, Almekinders et al., 1994). This situation, and the different paradigms discussed above, raises important questions about the optimal focus of R\&D efforts since such efforts can pull in very different directions. Emphasizing the development of the formal sector supply side of the seed value chain with breeding and quality seed is one strategy and represents a tremendous challenges in countries where institutions are still weak (see Atilaw et al., 2016 for Ethiopia). Investing in the farmers' end of the seed value chain involves for example, investing in farmers' capacity to maintain seed quality on-farm would result in farmers being able to better control degeneration processes, reducing their need to replace planting material with cleaner, healthier or genetically purer material, eventually making them less frequent buyers of seed. This clearly has implications for the financial model of those involved in multiplying and commercializing early generation seed material. In the following section we take a closer look at the way these issues and challenges play out in RTB seed supply and use.

Table 2 Key characteristics of common conventional propagation material of 4 RTB crops and maize (adapted from Andrade et al., 2016)

\section{How does evidence on RTB crops fit the seed system paradigms?}

RTB planting material is different in many ways from seed propagated crops (Table 2). The vegetative propagation through the use of stems (cassava, sweet potato), roots (yam), tubers (potato) or suckers (banana) means that they can be multiplied 'true to type', i.e. their genotype is fixed. At the same time, vegetative propagation makes them more vulnerable to the build-up of viruses and other pathogens, including soil-borne ones. Their bulkiness, the low multiplication rate and perishability has implications for the storability and transportation. These seed systems are therefore quite distinct. They are characterised by being more farmer dominated, only partially commodified, more dependent on public sector R \& D efforts and less formally regulated. In the following sections we explore how these factors influence variety use and improvement, seed production practices and replacement and, finally, the challenges of improving the functioning of the seed system.

\section{Adoption of improved varieties.}

The adoption of improved varieties varies greatly between different RTBs, countries, regions and continents (Walker \& Alwang, 2015). As indicated, the formal seed systems for RTB crops are relatively undeveloped, with the ones for potato probably the most advanced, at least in a number of countries. Overall the formal sector is much smaller than the farmer dominated part. For example, in Kenya there is a public and private potato seed sector with regulations on seed quality, variety release, but less than $1 \%$ of the farmers buy seed from a specialized seed source (Gildemacher et al, 2009). However, when comparing the adoption of improved varieties 
in different crops in sub-Saharan Africa, including grain staples, based on the data presented by Walker and Alwing (2015), there appears to be no evidence that the relatively underdeveloped status of RTB seed systems has had a detrimental effect farmers' access to improved varieties nor is there any evidence of a large, consistent difference between grain staple crops and RTB crops. The bulkiness and perishability and transport requirements of RTB planting material has not resulted in a general pattern of lower adoption rates across crops and countries. Walker and Alwing (2015) refer to the yam variety C18 in Cote d'Ivoire which, 10 years after its introduction, is estimated to cover $18 \%$ of the area planted with yam. The same authors do, nevertheless, point out that adoption levels of all crops in Sub Sahara Africa (SSA) are low and show that either diffusion, access or adaptedness of the improved varieties is a concern. Spielman and Smale (2016) observe the same, and focus on the low turnover of varieties, emphasizing that the adoption of improved varietiesis not an adequate indicator of how well the seed sector is functioning. They claim that a high adoption level of improved varieties with low variety turn-over would point to stagnation in the seed system and suggest instead that few new attractive varieties are available or accessible to farmers. They argue that this is the case in SSA for seed systems of grain crops. There are no data on this point for RTB crops.

\section{Diffusion of varieties and the dynamics of seed exchange}

The adoption of improved RTB varieties suggests that, despite being relatively ignored and the relative lack of private seed sector actors and regulation, variety diffusion of these crops may have fared relatively well. It is possible that for farmer-to-farmer diffusion, the negative aspects of bulkiness and low multiplication rate of RTB planting materials are off-set by the fact that the genetic character remains fixed in the multiplication which makes it relatively easy to multiply planting material of a new variety. On the other hand, the logical deduction from the low multiplication rates and high volumes of planting material that are needed compared to seedpropagated crops is that RTB seed systems are relatively 'local' and characterized by short transportation distances and a minimal need for storage. There are anecdotal cases in which 'escaped' improved varieties of RTBs from experimental stations have become popular and widely planted, indicating that the sharing of seed among farmers is commonplace. Shangi, now the most popular potato variety in Kenya and covering $70 \%$ of the area planted (GIZ, 2014), is such an example: the variety was still unknown in 2010 and is thought to be a clone from a CIP breeding program (E. Otieno, personal communication). Tadesse et al. (2016) found that farmers in Ethiopia who had received quality seed of a new improved variety from an NGO shared on average with more than 6 other farmers, mostly relatives, neighbours and friends. There are also many situations in which RTB planting material has been transported over longer distances without any formal organisational involvement. Specialized seed potato producers in the highlands of Peru sell seed to farmers on the coast (Bentley et al. 2001), farmers from the tropical lowlands in Bolivia travel to the highlands to purchase quality potato seed

(Almekinders et al., 2009) and potato growers in Malawi sell seed tubers to farmers from Mozambique (Netsayi, 2016). In East Africa, farmers who have some moist land may grow sweet potato which can then provide planting material to farmers in dryer areas (McEwan, 2016). Gibson (2013) found farmers traveling from Sudan to find sweet potato vines in Northern Uganda. In several instances these seed channels are facilitated by traders, resulting in the spread of new varieties over large areas and even crossing national borders. In Nigeria, the CMD resistant cassava variety MM96/0092 was adopted in this way even before the varieties were officially released (McNamara et al., 2012) travelling as far as DR Congo and Rwanda, where it was found in farmers' fields at least three years before it was officially released (S. Walsh, personal communication). Similar tales exist about the spread of Chingovwa, a white fleshed variety of sweet potato from Zambia, and NASPOT 1 an orange fleshed variety (M. McEwan, personal communication).

One element that may contribute to the diffusion of improved RTB varieties is the importance of these crops for farming households. RTBs are known to play an important role in food security, especially as an emergency and hunger crop (e.g. sweet potato in Rwanda, Mozambique and potato in Ethiopia). More recently their market 
value for smallholder farmers has also become increasingly important and visible. This is particularly the case when industrialized processing becomes more important, e.g. cassava in Thailand (Howeler, 2004) and more recently in Nigeria and Nicaragua (), but also where smallholder market production develops next to plantation production (e.g. smallholder banana production in Uganda for the Kampala market). The outbreak and rapid spreading of highly contaminating diseases affecting RTB crops must also increase farmers' interest in having access to planting material of improved resistant varieties and emphasizes the importance of farmer-based diffusion of new, improved varieties in the absence of a well-developed private or public seed supply. At the same time, we need to acknowledge that our knowledge of these farmer- based systems is only anecdotal. Most information on flows and mechanisms of seed exchange among farmers are from studies on grain crops (see Coomes et al.2015). Among RTB crops only informal seed systems for potato have been relatively well studied, predominantly from the Andes (e.g. Scheidegger et al, 1989, de Haan, 2009, Zimmerer, 1991). Fewer studies deal with cassava and or sweet potato (Prain et al, 2000, Adam, 2014, Coomes, 2010) and we found no studies of farmer-based yam and banana seed systems, despite the importance of the crop in West Africa and the almost complete absence of a formal seed system.

\section{Farmers' need for clean planting material and degeneration of seed quality.}

Until now we have mostly referred to farmers' interest in acquiring new varietal planting materials . Obtaining planting material of a new adapted variety is an important driver for farmers' interest in securing seed from outside the farm. Yet, farmers also look for seed from off-farm sources when they had a harvest failure or other reasons mean that they could not save sufficient seed for planting in the next season. Farmers may also be interested in off-farm seed to replace their own seed when it has lost its quality as a consequence of multiplication and saving seed over one or more seasons. There are four aspects of seed quality: the physiological (germination, vigour), genetic (varietal purity, adaptation), sanitary (absence of diseases) and the physical (percentage of good seeds) (FAO, n.d.). The loss of quality of any of four aspects from continued propagation is called degeneration. Compared to 'true' seed crops, RTB crops are more prone to the build-up of virus infection and contamination with soil-borne diseases, resulting in degeneration of the sanitary quality or health status of the planting material. The physiological quality xan also be an important concern because of the perishability of RTB planting material. Seed crops go through a cycle of 'true' seed which means that many diseases, including most virus diseases, are not taken forward to a next generation. For 'true' seed crops genetic degeneration is therefore more of a concern, especially in improved varieties of cross pollinating crops. For example, hybrid maize, sorghum and various horticultural crop varieties degenerate genetically and farmers using these varieties need to become repeated seed buyers of seed. Some farmers are known to reject hybrid varieties, even if these are economically more attractive, because it makes them dependant on the purchase of new seeds for each planting (Jones, 2013, Tripp, 2001). By contrast, once having obtained planting material of a desired RTB crop variety, the farmer can relatively easy genetically reproduce the planting material. These elements lead to relative differences in the importance of farmers' motivations for buying new seed in different crops. In RTB crops the degeneration of sanitary and physiological quality tends to be more pronounced and receives more attention from research than in grain crops.

Degeneration and the effect on yield in farmers' conditions is only well studied in potato (see Thomas-Sharma, 2016). Because the costs of quality seed are usually high, farmers need several seasons of multiplication to capture the benefits of their investment (Scheidegger et al., 1989). There is very little empirical information on farmers' practices and their decisions to replace degenerated planting material (the farmers' household economy) for other RTB crops. 


\section{Farmers' practices and degeneration of seed quality}

Farmers' practices for reproducing and multiplying seed affect the degeneration process. For potato there is a relative wealth of information on these practices and how they affect the degeneration process, maintaining the production potential of the planting material. We summarize the main findings of the literature below

- Most farmers integrate their seed production with the production of their ware crop. That is to say that they do not have specialized production plots or practices but rather select their seed tubers for the next season's planting by selecting tubers from the bulk harvest. In many cases they save the smallest potato tubers for seed. Small tubers have the advantage of producing the most stems per kg of saved tubers (), but they also increase the risk of saving diseased planting material: plants that are virus-infected or otherwise diseased tend to produce smaller tubers. Grading the harvest of potato tubers and saving the larger ones can reduce degeneration (). Lack of knowledge among farmers is an important explanation for the persistence of the practice of using small tubers (Tadesse et al., 2016) but even when informed, the practice persists because of the costs of planting material and the pressure for income and food (Mudege and Demo, 2016) When market prices are high or home consumption needs are pressing, it is difficult for farmers to save big first-quality grade tubers for next years' planting. The practice of selecting small propagules for planting is also reported for yam, which -as with potato, but different from sweet potato, cassava and banana - the planting material is also the consumed plant part.

- Farmers can practice roguing, eliminating diseased plants from the field, another practice that reduces disease pressure. Roguing is also called negative selection (Gildemacher et al., 2012). Also marking the healthy mother plants for harvesting seed (positive selection) reduces seed degeneration (SchulteGeldermann et al., 2012). Both practices involve a labour investment and require knowledge of disease symptoms, and (in many cases) disciplined action of the individual farmer or community to remove and destroy contaminated plant material in order not to leave sources for further spreading the disease, such as bacterial wilt is present (Ralstonia solanacearum).

- Farmers can replace part of their planting material with higher quality seed lots, rather than replacing their entire seed stock. The newer seed stock is either multiplied separately or mixed in with the existing seed lots. In the Andean regions these seed lots are already variety mixtures ().

- In some cases farmers use geographically isolated and/or off-season planting for producing high quality seed tubers. The different altitudes and planting seasons allow Andean farmers to specialize in producing seed tubers in conditions with lower virus and disease pressure for ware potato production in lower lying areas ().

- Storage conditions affect the quality of potato seed tubers. Effective traditional farmer practices to store potatoes are reported (), and improved diffuse light storage construction is commonly promoted to maintain physiological quality (controlling physiological age and sprouting). Improved practices require knowledge and capital which may be beyond the reach of poorer farmers (Tadesse et al., 2017). Improved storage can also have gender-related effects, e.g. when the man controls the resources and builds specialized constructions, but the knowledge for selecting the tubers rests with the women. Attention for on-farm storage practices for potato seed in relation with rotting, drying out, pest and disease incidence has received less attention.

The effect of these practices on degeneration and the impact on yields depends on the interactions with the biophysical environment, e.g. altitude, climate, and the crop. Thomas-Sharma et al (2015) provide an overview for potato. In general, when degeneration rates and effects on yields are high, farmers may be more willing to replace their own seed and invest in high quality seed. Availability and access will then be important: the seed has to be there in the right time at an affordable price. Information about farmers' practices, the interaction with the degeneration and yield for other RTB crops is rather scattered. Commercial banana plantations renew their plantings every 1-2 cycles, but smallholder farmers have varying practices: for example, in Uganda farmers often replace individual mats and fill gaps (Lwandasa, 2014, Kilwinger, 2017) whereas in Cameroon farmers establish 
new plantations as part of a shifting cultivation regimes (Kanmegne, 2004). Research in banana has shown that banana trees infected with bacterial wilt (Xanthomonas) do not necessarily transmit the disease to all the suckers that emerge from the same mat (Blomme et al., 2014), and a similar pattern has been found for virus infections in mother and daughter tubers in potato (Bertschinger, 1992). Work has recently started in eastern Africa to analyse the multiplication of sweet potato vines in nursery beds of specialized producers, which includes an evaluation of the use of net tunnels (). Such research findings help us to identify the improved practices that farmers adopt in order to reduce the rate of degeneration in RTBs. These farmer practices can be combined with contributions from formal R\&D over such issues as resistance breeding and rapid multiplication techniques and can together form the components for an integrated seed health strategy as has been suggested for potato (Thomas-Sharma et al., 2015): this is also applicable to other RTB crops.

\section{Farmers' demand for improved seed and technology: the overlooked social factors.}

Socio economic research shows that in many situations it is profitable for farmers to invest in quality seed. Willingness-to-pay studies indicate that many farmers are indeed prepared to pay surplus prices and attempt to identify the prices that farmers can afford. However, in practice, we find many farmers do not buy quality seed of adapted varieties even when it is available. Explanations are given in terms of: farmers lacking knowledge, not understanding or being reluctant to change, etc. Correlation-studies, usually based on surveys involving large number of farmers, often show that older farmers and those with less education are among the non-adopters. However, these studies can only provide a correlation between farmers' characteristics and (non-)adoption; they cannot unravel the causal relation. These studies easily overlook the cash constraints that some farmers experience and the risk and labour costs related with improved production techniques that affect adoption. These considerations lead poor farmers, often the elderly and with low education, to reject improved seeds and practices made available to them. In Chencha, Ethiopia, improved potato varieties were not useful for farmers because they lacked the skills, cash and labour to adopt them successfully (Tadesse et al, 2017). In Malawi, women buy cheaper seed, even when they know its quality is poor (Mudege and Demo, 2016). Introduced improved potato technologies have a higher yield potential but may not fit with the farmer-household economy (Tadesse et al, 2017). Farmer-demand for improved seed and technology is thus in many situations a fictive demand, based on expert estimation, not an effective demand. The fictive demand is normally used to calculate viability of seed multiplication initiatives, involving farmer groups, cooperatives or local entrepreneurs. Experience shows that many of these initiatives fail to become commercially viable. The reasons most likely vary, but because follow-up and in depth studies are scarce (Walsh, 2015), it is hard to prove that farmer-demand has been badly interpreted and, in the worst of cases, wishful thinking.

Recent case studies have yielded other some interesting findings that can help us to better understand farmers' motivations for using seed from different sources. Urrea et al. (2015) found that farmers select among seed lots not by reading labels, but by looking at the soil in the eyes of the seed tubers: this tells them where the seed tubers were produced. From this information they infer seed quality and other seed attributes that they are looking for. These are not simply highest economic gains, but include objectives like 'health' and 'living well'. From studies on seed and variety choices in other crops it is known that, contrary to productivist theory, farmers' motivations do not necessarily result in the technology choices that give highest yields or financial output per hectare ().

The complexity of farmer demand (McEwan et al, 2015) is defined through an aggregation of agro-ecological and socio-economic considerations at the individual and household level, and interwoven with other land, technology, and market options (e.g. Jones, 2012, Pircher et al., 2013, Tadesse et al, 2017). Interventions that assume that farmer demand for seed exists but is not being satisfied often fail to take these complexities into account (AGRA, 2016, BMGF, 2015). The assumption that, once suitable varieties are available and seed prices 
affordable, farmers learn over time that investing in quality seed is worthwhile is not supported by the empirical evidence..

\section{Lessons from the case studies}

Because RTB seed systems have received relatively little attention, a group of CGIAR-affiliated researchers undertook a multiple-case study of RTB seed system interventions. The growing awareness of the importance of RTB crops for food security, nutrition and the income of rural households, have led to an increase in the number of projects that introduce new RTB varieties and seed multiplication practices, especially in Africa (e.g. McEwan et al., 2015). Sometimes these interventions have 'seed' as a main focus, but often 'seed' figures as a component in a larger agricultural development project. In an effort to understand the landscape of interventions in RTB seed systems and draw lessons for research and development practice, 13 case studies were selected. The case studies were carried out on the basis of available documentation and personal experiences of the researchers responsible for the case-study. For a number of case studies some additional information was collected through short interviews with involved stakeholders (usually by phone or skype). These case studies are compiled and practical cross-case lessons have been drawn (Andrade et al., 2016). Summaries of the case studies are presented in table 1.

\section{The landscape: the diversity of type of interventions, the actors and their and their goals}

A first observation from the selection of the cases is the diversity of type of interventions. They show that many actors are involved in seed system interventions. First of all, there are the regular players: public sector researchers and breeders. In addition, NGOs and donors are influential players and they come in all shapes and sizes. NGOs have largely filled the gap left after structural adjustment decimated extension services in many countries (Walsh, 2008). Donors also play an important role. Such support has always reflected the dynamics/models of development-thinking in donor countries, be that of governments from industrialized countries or alternative-thinking NGOs. Large philanthropic foundations with huge budgets have recently emerged into this landscape, adding to the diversity. This also leads to different scales of interventions, with everything from micro-local scale initiatives involving a few dozen of farmers to national and macro multicountry scale interventions. Related to these different scales is the variation of purposes/goals of interventions. The 13 interventions were justified to: support seed system development, to mitigate a crop disease emergency (e.g. cassava planting material) to improve food security and nutrition, (e.g. orange-flesh sweet potato and biofortified varieties), to meet the new opportunities of developing markets, or to promote the adoption of new varieties and technologies (see table 2). While ambitious in their goals, most interventions were short-term (on average 2-4 years) and there was usually no mention of clear linkages to national or regional seed system development strategies, policies and structures.

\section{Understanding the systems in which projects intervened}

In none of the projects did we find any systematic analysis of the seed system they were intervening in, which in all cases was predominantly farmer-based. Nor were there deliberate efforts to build on the farmer-based seed system, e.g. by involving farmers who were known as local seed experts or by taking advantage of existing delivery channels. For emergency interventions the opportunities for a diagnosis prior to bringing in the seed is obviously time-constrained. Nevertheless, as McGuire and Sperling (2016) observe, such blind introduction often leads to introduction of unadapted varieties and the destruction of local seed markets.

Several interventions implicitly or explicitly assumed that smallholders would specialize and be able to function as suppliers of quality planting materials on an entrepreneurial basis. We found no evidence of farmer-demand assessments, implying that most interventions are based on expert-assumptions about farmer demand. This 
suggests that most interventions are supply driven and that there is still a lack of understanding of farmer demand for seed. A study on traditional sweet potato vine multipliers argued the need and urgency to link these traditional vine suppliers to scientists and extension agents to enable them to access improved varieties, vine production technologies and make these locally available for other farmers (McEwan et al. 2015, Adam, 2014, Obong et al., in review)

Other interventions, notably the promotion of bio-fortified cassava, sweet potato varieties and banana () are more associated with the nutrition and health sector, are have a stronger focus on supporting women, better health and child rather than seeking aggregate increases in agricultural output. As a result they do not seek to tap into the existing seed system where key seed-actors can potentially reach numerous smallholder farmers. Nonetheless in some cases they have achieved impressive adoption rates, as for example in the case of orange flesh sweet potato (OFSP) varieties in Mozambique, which are now being grown by numerous women in small patches (). The case of sweet potato in Rwanda case also stands out as the project made an effort to develop a value chain, from the supply of vines for planting by specialized farmer groups to processing and marketing.

Many of the interventions made use of rapid multiplication techniques for producing clean planting material: aeroponics for potato, mini-setts for yam, tissue culture for banana. These techniques were used to provide farmer groups with clean, high quality planting materials that they could further multiply and commercialize. Based on the information we have, we could not determine how recipient farmers were identified and if they were potentially logical source-farmers. This is relevant because strategic distribution of small lots of high quality seed to such farmers could make such materials available and accessible to a wide range of farmers, and upgrade the health status of planting materials in the entire local system. The opportunity of selling the harvest in lucrative niche markets created a concrete demand by farmers for quality seed, but involved only a relatively small group of farmers. We know little about the way other farmer groups or local multiplication initiatives met

farmer demand in other initiatives. There are the banana nurseries which are expected to meet the need of banana farmers who traditionally rely almost entirely on the farmer-based system and now face Banana Xanthomonas Wilt (BXW) or Banana Bunch Top Virus (BBTV) in various parts of Africa (). Similarly, decentralised multipliers (DM) of sweet potato vines are operating in Eastern Africa to make sure that farmers have access to quality planting materials when the rains start (McEwan et al, 2015). The technical and economic viability of these DMs is not yet clear.

\section{The need to reflect and learn from experiences}

The case study documents did not provide the information required for understanding 'when farmers actually buy seed' or 'how farmer demand can sustain a specialized seed production endeavor'. The understanding of the existing seed system in which the intervention was placed, usually involving local technicians and development practitioners, did not seem to be taken into consideration in the design of the interventions. In addition it was hard to find post-intervention evaluations and reflections.

\section{Reflection and a research agenda}

Two crucial assumptions on making quality seed available and accessible to farmers show up repeatedly in the literature and the case studies: 1) that there exists a demand of farmers for quality seed and 2) that this demand for seed can be the basis for specialized seed production and commercialization that is economically viable. As we indicated earlier, a demand for seed can only be assessed if it is an effective demand, which assumes the available and accessibility of quality seed from seed supplying sources, such as decentralized multipliers, specialized farmers or farmer-groups seeking an income from seed production. We reflect on these two assumptions for RTB crops. 
Farmers are willing to pay a premium price RTB planting material of a new variety which they would like to plant. Because RTBs are vegetative propagated, farmers can relatively easy multiply the newly acquired variety. This raises the question of how often will they resort to buying new planting material of varieties rather than saving seed from their own harvest. A farmer needs to find new planting material a failed harvest or when (s)he was not able to save seed for other reasons, but this represents a variable and rather unpredictable demand. Another situation is when the farmer cannot store the planting material because the storage season is too long or when storage conditions are unfavourable. In this case, local producers can specialize when having access to water or cooled storage facilities, like in the case of DM of sweet potato vines in eastern Africa (McEwan et al, 2015) or the use of commercial cooled storage for potato seed tubers in lowland tropics (Bangladesh). More distant production areas with different conditions can also become important sources of seed, as described in 3.2. The third situation is when seed has degenerated as result of reproduction and results in lower harvests. For potato the general rule of the thumb seems to be that when degeneration rates are high, or when farmers cannot store, farmers are more likely to buy seed and buy seed more frequently. This is likely to hold for other RTB crops as well. However, the offered varieties, the quality of the seed, timely availability and price all define the effective demand.

The option of improving seed availability and access through decentralized multiplication by specialized seed producers has been widely explored and is believed to be a solution for situations where the public sector is failing and large-scale private sector companies are not interested (FAO and ICRISAT, 2015, AGRA, 2016). Moreover, such local seed production may generate local employment and income, especially for women's groups or young people. From the perspective of DMs, the preferred client is a farmer who uses seed as a onetime use input. In any case, a specialized seed production enterprise needs a regular number of returning buyers. Next to the volume and stability of the demand, there are more challenges around the DM model need to be addressed. DMs are mostly thought of as farmer groups, cooperatives or individual local entrepreneurs, the actors who are seen as potentially key in building bridges between the formal and farmer systems (FAO and ICRISAT, 2015, AGRA, 2016). A variety of forms of DMs were advocated and initiated in the 1980s (Camargo et al., 1989, Friis Hansen, 1989, Davies, 2004, Rohrbach et al, 2002) but we find few sustainable examples to highlight the success of the concept. The RTB crops seem to be particularly in need of such interface actors because of the bulkiness and the perishability of the planting material. However, the experiences and the argumentation show various tensions. DMs are considered to be particularly appropriate for crops that are less attractive for the private sector. This is the case for RTBs. Local producers may be able to produce at lower costs and with lower transportation costs. But they face other challenges. Often they have relations with their clients that complicate a business-approach to transactions. Traditionally, especially in vegetative propagated crops that are important for local food security, it is considered inappropriate to pay, or ask for, cash for planting material (Ngabo, 2015, Kilwinger, 2017, Kansiime and Mastenbroek, 2016). Experiences show that this may be partly overcome when the DMs have a new variety. Farmers recognise the value of the novelty and have shown to be willing to pay cash, even a premium price. A recent study (Tadesse et al. 2016) on the introduction of potato tuber seed of a new variety in an Ethiopian farmer community showed that in $82 \%$ of the cases this seed was shared among family friends and neighbours, but they also found that in $43 \%$ of all sharing involved a cash transaction. However, to have regular influx of new varieties, the DMs need to be well connected with a wellfunctioning system that provides new varieties to allow a high variety turn-over in the DMs portfolio. Another issue is that while production in the vicinity can reduce transportation costs and logistics, it also implies the specialized producer and farmer-client sharing the same production conditions. If the farmers experienced a difficult cropping season than this will also have been the case for local DMs, which leads to the counter-cyclical demand for seed (Jansen, 1989), which is not an easy proposition under a commercial set up. This may be further complicated when the government or another actor decides that an emergency intervention is needed to provide farmers with planting material for free, or just because free seed hand-outs fit the political elections campaign. More recently potato cooperatives and farmer groups have been set up and supported in Ethiopia and Uganda in 
the context of the ISSD concept (Alemu et al., 2013, Mubangizi et al., 2013). These group and community based forms of seed multiplication are not new: they have been promoted since the 1980s (Camargo et al, 1989, FriisHansen, 1989, Davies, 2004, Rohrbach et al, 2002) but so far they have been unable to become a prominent form of decentralized seed supply (Walsh et al, 2015). From this it follows that we need a better understanding of the underlying issues when setting up DM in RTBs that involve local farmer groups and/or other local forms of multiplication of planting material (see also FAO and ICRISAT, 2015).

Finally, we need to better understand how and what kind of regulations and supporting policies can enhance the availability and access to quality planting material by farmers? Each seed system intervention, irrespective of its scale and time-scope, relates with existing and/or desirable policy regimes. Certification schemes in potato have shown to increase the costs of planting material for farmers to prohibitive levels. In addition, in many countries the legislation is not well enforced, leaving ample space for selling low quality or contaminated planting material. QDS is believed to be a more appropriate quality regime for the conditions in developing countries, but there is no evidence for this yet. Farmer groups and cooperatives may have difficulty in maintaining seed quality because they lack the knowledge or their agreed procedures do not match their social culture, as is recently reported for two potato cooperatives in Ethiopia (Tadesse et al., in review) Different forms of subsidies, like f.e. the use of vouchers (Walsh et al., 2006) can make seed of new varieties more accessible to farmers, but it is not clear how this affects the recurrent purchasing of seed to replace degenerated planting material or what happens when the subsidies are removed. Studies in seed crops have shown that farmers may return to the low-cash and low-risk practices of using their own farm-saved seed and local varieties.

We also need to ask how changing socio-economic context modify these relationships. Will farmers invest more in a crop when they can sell the harvest for more reliable and profitable prices, and will this increase farmers' demand for off-farm seed? And, if such profitable markets develop, will they be accessible for all, on equal terms? Will the poorest farmers also be able to access quality seed? And will all farmers respond similarly to production opportunities in a context of labour scarcity, climate change, migration and remittances?

What emerges from this study is the very real need for seed system interventions to be more aware of the system and context in which they are operating and to assess the potential of using traditional channels and actors for seed distribution. Surveying has generally been the main mechanism for generating data on the existing systems. But more tools and methods are available and these could lead to more incisive reflection among actors, allowing them to reorient their interventions if necessary. Expert consultation employing, e.g. reflection frameworks () or network analysis approaches () offer opportunities to generate timely, more realistic and sociotechnically integrated information, that give a central place to how farmers' access quality seed. These tools can combine biophysical with socio-economic interactions and lead to more integrated understanding. With such tools, seed projects will be sufficiently equipped to frame interventions as action-oriented research with clearly formulated (research) hypotheses and a plan for data collection. Integration of such data collection into the monitoring and evaluation system will contribute to more critical reflection and learning on the effects of interventions in complex systems (Arkesteijn et al, 2015, Jones, 2011).

\section{Conclusions}

In 1999 Thiele reported that none of the potato projects he had studied had published systematic information about how farmer-based seed systems worked or the costs and benefits associated with interventions. These features are essential for any meaningful evaluation. He also wrote that, under these circumstances, adherence to one or other of the strategies has more to do with beliefs about the nature of development than with scientifically grounded theory or data. Not much has changed since: there is only anecdotal information on the farmer-based seed systems, they are not considered when designing interventions and we are notoriously bad at reflecting on 
our experiences with seed system interventions, and evaluating them so they can be used to inform future interventions. This holds for potato, other RTB crops, and probably grain crops as well.

Another point of concern is how the understanding of farmer-based seed systems is used to re-orient ongoing, and to design future seed system interventions. Some may strongly feel that supporting on-farm seed production does not contribute to highly productive agriculture, whereas others may consider that the 'advanced' mature seed system model has proven to be unfit for purpose in many developing countries. Both sides can make their case, but in the meantime the world is rapidly changing. Markets and information provision are rapidly changing the life of the poor in many different ways. Climate change, migration and urbanization are other global developments that will radically change smallholder farming in the future (Zimmerer and De Haan, in preparation). This suggests that what did not work in seed system interventions yesterday may work today or tomorrow (and vie-versa) and stresses the importance of not being boxed into conventions but of paying attention to what works where, and for whom, and how to scale up good practices.

\section{Acknowledgement}

The authors acknowledge the input of collaborators who contributed through the discussions during multiple workshops of the RTB seed system program. This publication has been co-funded by the CGIAR Research Programme.

\section{References}

Adam, 2014, Gender and the dynamics of distribution of sweet potato planting materials among small holder farmers in the Lake Victoria Zone region, Tanzania. PhD Thesis Pennsylvania State University.

Abidin, P.E., 2016. Quality declared planting materials (QDPM) standards and inspection procedures in Ghana. Working Paper CIP, July 2016 DOI: 10.13140/RG.2.2.33712.97284

AGRA, 2014. https://agra.org/news/agra-signs-seed-industry-development-agreement-with-africandevelopment-bank/ (accessed 12-2-1017)

AGRA, 2016. https://agra.org/news/africa-must-increase-local-production-of-improved-seeds/ (accessed 12-22017)

Alemu D., Yohannes Tesfaye, Amsalu Ayana and G. Borman, 2013. ISSD Briefing Note - April 2013. Uganda Seed Entrepreneurship Assesment.

Almekinders, C., R. Cavatassi, F. Terceros, R. Pereira \& L. Salazar, 2009. Potato seed supply and diversity: dynamics of local markets of Cochabamba Province, Bolivia - A case study. In: L Lipper, C.L. Anderson, \& T. J. Dalton (Eds), Seed trade in rural markets. Implications for crop diversity and agricultural development. Earthscan, London, p. 75-94

Almekinders, C.J.M., N.P. Louwaars, and G.H. De Bruijn 1994. Local seed system and their importance for an improved seed supply in developing countries. Euphytica 78:207-216.

Andrade-Piedra, J., J.W. Bentley, C. Almekinders, K. Jacobsen, S. Walsh and G. Thiele, 2016. Case Studies of Root, Tuber and Banana Seed Systems. Working Paper CIP.

Arkesteijn, M. B van Mierlo and C. Leeuwis. The need for reflexive evaluation approaches in development cooperation. Evaluation 21(1): 99-115.

Atilaw, A., D Alemu, Z Bishaw, T Kifle, K Kaske, 2016. Early generation seed production and supply in Ethiopia: Status, challenges and opportunities. - Ethiopian Journal of Agricultural ...,

Bill \& Melinda Gates Foundation and USAID, 2015. Early Generation Seed Study, a report compiled by Monitor-Deloitte and commissioned by BMGF and USAID. BMGF, Seattle WA, and USAID, Washington DC. $122 \mathrm{p}$

Bishaw, Z. and Atilaw A., 2016. Enhancing Agricultural Sector Development in Ethiopia: the role of Research and Seed Sector. Ethiopian Journal of Agricultural Sciences 
Camargo, C .P, C. Bragantini \& A . Monares, 1989. Seed production systems for small farmers: a nonconventional approach. CIAT, Cali, Colombia.

Coomes, O.T., McGuire, S. J., Garine, E., Caillon, S., McKey, D., Demeulenaere, E., Jarvis, D., Aistara, G., Barnaud, A., Clouvel, P.. Emperaire, L., Louafim, S., Martin, P., Massol, F., Pautasso, M., Violon, C., Wencélius, J., 2015. Farmer seed networks make a limited contribution to agriculture? Four common misconceptions. Food Policy 56: 41-50.

Coomes O. T., 2010. Of Stakes, Stems, and Cuttings: The Importance of Local Seed Systems in Traditional Amazonian Societies. The professional Geographer 62: 323-334. http://dx.doi.org/10.1080/00330124.2010.483628

Cromwell, E. 1990. Seed diffusion mechanisms in small-scale farmers' communities: lessons from Asia, Africa and Latin America. Agricultural Administration (Research and Extension) Network. Paper No 21. London, UK: Overseas Development Institute.

De Haan, S., 2009. Potato diversity at height: Multiple dimensions of farmer-driven in-situ conservation in the Andes. PhD thesis Wageningen University, Wageningen,

David, S., 2004. Farmer seed enterprises: A sustainable approach to seed delivery? Agriculture and Human Values 21 (4): 387-397

Douglas, J .E, 1980. Successful seed programs. A planning and management guide. Westview Press, Boulder.

FAO \& ICRISAT, 2015. Community Seed Production, by Ojiewo CO, Kugbei S, Bishaw Z \& Rubyogo JC, eds. Workshop Proceedings, 9-11 December 2013. FAO, Rome \& ICRISAT, Addis Ababa. 176 pp.

FAO, n.d. Seed and Seed Quality: Technical Information for FAO Emergency Staff. FAO Rome

Friis-Hansen, E., 1989 . Village-based seed production. ILEIA Newsletter 5 (4) : 26-27 .

Mudege, N. and P. Demo Seed potato in Malawi: Not enough to go around. In: J. Andrade-Piedra, J., J.W. Bentley, C. Almekinders, K. Jacobsen, S. Walsh and G. Thiele (eds), 2016. Case Studies of Root, Tuber and Banana Seed Systems. Working Paper CIP.

Gibson, R.W., Mwanga, R.O.M. , Namanda, S. , Jeremiah, S.C. and Barker, I., 2009. Review of sweetpotato seed systems in East and Southern Africa.International Potato Center (CIP), Lima, Peru. Integrated Crop Management.Working Paper 2009-1. 48 p

Gibson, R. W. 2013. How sweetpotato varieties are distributed in Uganda: Actors, constraints and opportunities. Food Security 5:781-791.

Gildemacher PR, Leeuwis C, Demo P et al., 2012. Positive selection in seed potato production in Kenya as a case of successful research-led innovation. International Journal of Technology Management \&Sustainable Development 11, 67-92.

GIZ, 2014. Post-harvest losses in potato value chains in Kenya. Analysis and recommendations for reduction strategies.

Howeler, R.H. 2004. Cassava in Asia: present situation and its future potential in agro-industry. Centro Internacional de Agricultura Tropical (CIAT), Cassava Office for Asia, Bangkok.

iPES-Food, 2016. From Uniformity to Diversity. A paradigm shift from industrial agriculture to diversified agroecological systems, International Panel of Experts on Sustainable Food Systems.

Janssen, W., 1989. Bean seed supply systems for small farmers: the need for primary data in institutional design. CIAT, Cali.

Janssen, W., C .A. Luna \& M.C. Duque, 1992. Small-farmer behaviour towards bean seed: evidence from Colombia . J . of Applied Seed Production 10: 43-51.

Jones, K., 2013. The political ecology of market-oriented seed system development and emergent alternatives. Conference paper for discussion at: Food Sovereignty: A Critical Dialogue. International Conference September 14-15, 2013. Program in Agrarian Studies, Yale University.

Jones, H., 2011. Taking responsibility for complexity. How implementation can achieve results in the face of complex problems. ODI Working Paper 330. London. 
Jones, R.B., Audi, P.A., and Tripp, R. (2001). The role of informal seed systems in disseminating modern varieties: example of pigeon pea in semi-arid area of Kenya. Experimental Agriculture, 37 (4): 539-548.

Kanmegne J (2004) Slash and burn agriculture in the humid forest zone of southern Cameroon: soil quality dynamics, improved fallow management and farmers' perceptions. Tropenbos-Cameroon Series, Publication, No. 8. Tropenbos.

Kansiime, Monica K., A. Mastenbroek, 2016. Enhancing resilience of farmer seed system to climate-induced stresses: Insights from a case study in West Nile region, Uganda. Journal of Rural studies 47: 220-230 http://dx.doi.org/10.1016/j.jrurstud.2016.08.004

Kilwinger, F. 2017. MSc Thesis, Wageningen

Lion, K.D., W.S. de Boef, M. Huisenga and D. Atwood, 2015. Convening report: Multiple Pathways for Promoting the Commercial and Sustainable Production and Delivery of Early Generation Seed for Food Crops in Sub-Saharan Africa, 23 March 2015, London. Bill \& Melinda Gates Foundation, Seattle, WA, and United States Agency for International Development, Washington, DC.

Louwaars, N. and W. de Boef, 2012. Integrated seed sector development in Africa: a conceptual framework for creating coherence between practices, programs and policies. Journal for Crop Improvement 26: 39-59

McEwan, M., C. Almekinders, P.E., Abadin, M. Andrade, E.E. Carey, R.W. Gibson, A. Naico, S. Namanda and S. Schultz, 2015. Was small ever beautiful? Moving local sweet potato seed systems to scale in subSaharan Africa. In: Low, J.;Nyongesa, M.;Quinn, S.;Parker, M. (Eds). Potato and sweetpotato in Africa: transforming the value chains for food and nutrition security. CABI, UK, p. 289-310,

McGuire, S.J., and Sperling, L. (2016). Seed systems smallholder famers use. Food security. DOI 10.1007/s12571-015-0528-8

Mubangizi E., W. Mesigwe Thembo and M.Thijssen, 2013. ISSD Briefing Note - April 2013. Uganda Seed Entrepreneurship Assesment.

Ngabo, P.V., 2015. Smallholders' access to quality sweet potato vines in the Lake zone, Tanzania:The case of Mwanza. MSc thesis Lwandasa,H., G.H. Kagezi, A.M. Akol, J.W. Mulumba, R. Nankya, C. Fadda and D.I. Jarvis, 2014. Assessment of farmers' knowledge and preferences for planting materials to fill-gaps in banana plantations in southwestern Uganda. Uganda Journal of Agricultural Sciences, 2014, 15 (2): $165-178$

Louwaars, N., \& de Boef, W., 2012. Integrated seed sector development in Africa: a conceptual framework for creating coherence between practices, programs, and policies. Journal of Crop Improvement, 26, 39-59.

Obong, Y., T. Omony, P. Rachkara, and R. Gibson. Disseminating modern sweet potato varieties using participatory variety demonstration trials on informal nodal multipliers' fields at hub locations. Journal of Crop Improvement (in review)

Pircher, T., C.J.M. Almekinders and B.C.G. Kamanga, 2013. Participatory trials and farmers' social realities: Understanding the adoption of legume technologies in a Malawian farmer community. International Journal of Agricultural Sustainability 11 (3): 252-263

Rohrbach, D D and Saadan, H M and Monyo, E S and Kiriwaggulu, J A B and Mtenga, K and Mwaisela, F, 2002) Comparative study of three community seed supply strategies in Tanzania. Project Report. International Crops Research Institute for the Semi-Arid Tropics, Bulawayo, Zimbabawe.

Scheidegger, U., G. Prain, F. Ezeta, C. Vittorelli, 1989. Linking formal R \& D to indigenous systems: a useroriented potato seed program for Peru. Agricultural Administration (Research and Extension) Network Paper 10. ODI, London.

Schulte-Geldermann, E., P.R. Gildemacher, P.C. Struik, 2012. Improving seed health and seed performance by positive selection in three Kenyan potato varieties. American Journal of Potato Research 89: 429-37

Scoones, I. and J.Thompson, 2011. The politics of seed in Africa s Green Revolution: alternative narratives and competing pathways. IDS Bulletin 42(4): 1-23

Scoones, I., and J. Thompson, 2011. The Politics of Seed in Africa's Green Revolution: Alternative Narratives and Competing Pathways. IDS Bulletin 42 (4): 1-23. 
Tadesse Y., C.J.M. Almekinders, D. Griffin, and P.C. Struik, submitted. Collective production and marketing of quality potato seed: Experiences from two cooperatives in Chencha, Ethiopia.

Tadesse, Y., C.J.M. Almekinders, R.P.O. Schulte and P. C. Struik, 2017. Understanding farmers' potato production practices and use of improved varieties in Chencha, Ethiopia: implications for technology interventions (submitted).

Tadesse, Y., C.J.M. Almekinders, R.P.O. Schulte and P.C.Struik, 2016. Tracing the seed: seed diffusion of improved potato varieties through farmers' networks in Chencha, Ethiopia. Experimental Agriculture. https://doi.org/10.1017/S001447971600051X

Thiele, G. 1999. Informal potato seed systems in the Andes: Why are they important and what should we do with them? World Development 27(1):83-99.

Thomas-Sharma, S., Abdurahman,A., Ali,S., Andrade-Piedra,J. L., Bao,S., Charkowski,A. O., Crook, D., Kadian, M., Kromann, P., Struik,P. C., Torrance, L., Garrett,K. A. and Forbes,G. A. (2015). Seed degeneration in potato: the need for an integrated seed health strategy to mitigate the problem in developing countries. Plant Pathology. Doi: 10.1111/ppa.12439

Thomson, J. R, 1979, An introduction to seed technology. CABI Leonard Hill, pp 252

Tripp, R., 2001. Seed provision and agricultural development. ODI and James Curry, London.

World Bank. 2003. Reaching the rural poor, a renewed strategy for rural development.Washington, D.C.

Spielman D.J., and M. Smale, 2016. Policies options to accelerate variety change among smallholder farmers in South Asia and Africa south of the Sahara.

Urrea, C., C.J.M. Almekinders, Y. van Dam, 2016. Understanding perceptions of potato seed quality among small-scale farmers in Peruvian highlands. NJAS Journal of Life Sciences. doi:10.1016/j.njas.2015.11.001

Van Mele, P., J. W. Bentley, and R. Guéi 2011. African Seed Enterprises: Sowing the Seeds of Food Security. Wallingford, UK: CABI. 236 pp.

Walker T. and J.Alwang, 2015. Crop improvement, adoption and impact of improved varieties in food crops in sub-Saharan Africa. CGIAR and CABI.

Walsh, S. T. Remington, S. Kugbei and C.O. Ojiewo, 2015. Review of Community Seed Production Practices in Africa Part 2: Lessons Learnt andFuture Perspective. In: FAO and ICRISAT, 2015. Community Seed Production, by Ojiewo CO, Kugbei S, Bishaw Z \& Rubyogo JC, eds. Workshop Proceedings, 9-11 December 2013. FAO, Rome \& ICRISAT, Addis Ababa. 176 pp.

Walsh, S., 2008. Leveraging NGO’s for Scale and Impact. Lessons Learned from the Crop Crisis Control Project. CRS, Bujumbura. http://www.crs.org/sites/default/files/tools-research/c3p-leveragingnongovernmental-organizations-for-scale-and-impact.pdf

Walsh, S., B. Odero-Onyango, H. Obiero (2006). Pilot use of on farm vouchers to disseminate cassava planting material in Western Kenya. C3P Brief No. 5. IITA and Catholic Relief Services. http://www.crs.org/research-publications/solrsearch?f\%5B0\%5D=field program area\%3A592\&f\%5B1\%5D=field location $\% 3 A 758$ 


\section{Table 1. Summary of 13 case studies of RTB seed system interventions (based on Andrade et al., 2016)}

\section{CONPAPA (Consortium of Small Potato Producers), Ecuador}

CONPAPA has its roots in a Farmer Field School (FFS) project in which the implementers aimed to increase small holders' access to a new variety of good frying quality potatoes (INIAP-Fripapa, 1992) so that they could link to a highly profitable niche market for quality table potatoes and increase unit returns and incomes. From 2001 onwards, INIA supported training on (conventional) seed multiplication, and farmer organization around seed production and marketing. CONPAPA currently operates in three provinces and involves approximately 500 farmers, 35 trained seed producers, and has an estimated annual production of 250 tons of farmerproduced seed. CONPAPA has shown itself to be able to control quality in absence of functional formal regulations. The initiative triggered the national regulation to accept the QDS-system (?). These experiences raise questions about the scalability of the initiative: whether to let CONPAPA grow (which may be problematic because of the size of the niche market), or to multiply the initiative (for which more specific market opportunities and linkages are needed).

\section{Aeroponic seed and native potatoes in Peru}

This project was an initiative of the corporate responsibility programme of a mining company to support farmers close to the mine in improving their potato production and income - representing a model for sustainable development. The project trained farmers (in FFS format) to form associations to produce and supply native potato varieties for supermarkets in Cajamarca and the coastal region at premium prices - and tap into the gastronomic revival of native varieties in Peru. Because there was no source of clean native potato seed available, a hydroponic based seed production in a greenhouse was set up to provide these farmers with pre-basic seed. Yields increased substantially, but the authors reckon that the multiplication system would collapse in without support because of its costly set up and substantial external expertise. Working together and in partnership turned out to be challenging for the farmers (due to mistrust). The need for some kind of internal seed quality control has been pointed out.

\section{Crop protection practices for cleaner seed yam production in Central Nigeria}

The rather small scale initiative (2003-2005) under the leadership of the International Institute of Tropical Agriculture (IITA) and funded by DFID/UK, explored the use of adapted yam mini-sett technology (AYMT) and how to validate and disseminate it. Principally, AYMT involves using slightly larger cuttings from yam roots, which reduces the multiplication rate but increases the germination and survival rate after planting in the field compared to the YMT. The use of seed yams produced from mini-sett technology was initiated in the 1970s, principally to reduce the cost of production and increase the volume of planting material, but take-up has been slow. The project used on-farm training and demonstration plots to promote the technologies. The pesticide adapted mini-sett treatment (a combination of fungicide + insecticide) give the best and most consistent results in terms of percentage sprouting, final yield and quality of seed yams. A major obstacle to farmers' adopting the practice is thought to be the reliability and (financial) accessibility of the chemicals needed for treating the propagation materials.

\section{Bananas and Plantains in Ghana}

Bioversity International and the International Institute for Tropical Agriculture (IITA) partnered with the Crops Research Institute (CRI) and World Vision to multiply and distribute new disease resistant plantain and banana cultivars for on-farm testing. The dissemination pathways of the planting materials were primarily managed by the project. The goal was that farmers would eventually continue dissemination of the planting materials of the hybrid-bananas within their own communities. Between 2003 and 2005 a total of 16,282 hybrid plants were disseminated to 887 farmers. Farmers also received training in rapid macro-propagation techniques for clean seed multiplication, improved agronomic practices, marketing, and post-harvest handling (e.g. cooking duration) of the fruits. After initial hesitation, farmers embraced the unfamiliar planting material, particularly after observing the vigor and healthy foliage of some of the hybrids. Problems encountered included: the economic viability of the rapid multiplication nurseries (limited profit margins associated with the high cost of (transport of) the plantlets in the absence of irrigation; rapid multiplication is currently used primarily by extension services and by CRI); delayed delivery of planting material (during the dry season without irrigation); some plants were infected with BSV (a risk associated with tissue cultured hybrids); a lack of knowledge of the informal seed system and low engagement with farmer networks (as the project preferred to work with extension services and research organizations).

\section{Marando Bora Sweet Potato Seed Systems in Tanzania}

The Moranda Bora project (2009-2013) aimed to reach 150,000 farming households with quality sweet potato vines of 6 improved varieties. It was funded by the Bill \& Melinda Gates Foundation and its implementation was coordinated by the International Potato Center in collaboration with a network of public and private partners, whose delivery objectives were the responsibility of Catholic Relief Services (CRS). The improved varieties were initially propagated in-vitro by KEPHIS and a private sector laboratory. For the multiplication and dissimilation the project used 2 approaches to get materials out: 1) decentralised vine multipliers (DVMs) and 
after this approach showed flaws) 2) a mass multiplication approach. The project reached 112,000 farmers in 16 districts through 88 decentralized vine multipliers. The project set-up was designed to evaluate a number of aspects (the use of net tunnels to reduce degeneration, the use of vouchers, vine quality maintenance). However, the implementers reckon that the question of when farmers will commercially purchase vines remains unanswered. The business model for the DVMs thereby remains unstable. They also see potential in working more closely with existing informal seed multipliers.

\section{Testing Market Driven Commercially Oriented Sweet Potato Seed Value Chains in Rwanda}

The SASHA SuperFoods project (2010-2014) promoted white and orange flesh sweet potato (OFSP) produce in order to create a demand for, most of all orange flesh (which is rich in vitamin A), sweet potato roots and associated seed and create a positive impact on the incomes and nutrition of the poor, in particular women. This was an effort funded by the Bill \& Melinda Gates Foundation which was led by the International Potato Center (CIP) in collaboration with Rwanda Bureau of Agriculture (RAB) and Catholic Relief Services (CRS). With a value chain focus, the project facilitated linkages between sweet potato farmers and a large scale bakery which offered a premium price for roots used in making processed products such as biscuits and mandazis (local donuts). The initiative tested two organizational models for the multiplication and dissemination of vines for planting: one involving 20 existing farmer groups (the majority of whose members were women) and a second based on collaboration with 40 individual farmers, over half of whom were women. In the absence of any formal quality regulation, the farmers were supported in producing quality planting materials of improved sweet potato varieties, including the use of low-cost net tunnels to reduce virus infection. Providing clean tissue cultured material to these farmers was problematic. The demand for the vines was mostly from NGOs and farmers in nonintervention areas (who looked for the OFSP). Otherwise, the experience showed that farmers who had an assured market for their roots had more interest in quality vines for planting.

\section{$3 G$ Potato Strategy in Kenya}

USAID provided CIP with a grant to increase quality seed potato supplies through public and private sector collaboration to link-in and increase investment private sector in seed potato production, raise and decentralize national production of basic seed potato, improve access to quality seed and the quality of farm saved seed and to enhance the adoption of diffused light stores. The activities (2008-xxxx) included collaboration with multiple stakeholders in Kenya, Uganda and Burundi, but most efforts (as well as the case study) concentrated on Kenya. The intervention is perceived to be highly successful. More than 100,000 in-vitro plants have been produced, 1 million mini-tubers, with 52 ha under G2 seed and 921 tons of G3 seed harvested through a public and private sector network of more than 60 multipliers. The fourth generation seed tubers (G4) were all sold, and in general at lower prices than third generation seed tubers (G3), and often at lower prices than seed in the informal sector. The ware yields of the first generation of potato were 150-200 \% higher. The experience shows that aeroponics can be technically and financially viable as a basis for a seed multiplication within a seed program; that awareness creation increased the demand for quality seed, and that positive selection slows down the degeneration process.

\section{Reforming the National Cassava Seed Sector in Nicaragua}

In recent years, the interest in cassava has grown, mainly as a reaction to the private sector investing in large-scale cassava agroindustrial processing projects, targeting export markets. As a result of these developments, the national institution in charge of technology development, INTA (Instituto Nicaraguense de Tecnologia Agropecuaria) has re-started its work with (six) improved cassava varieties which were obtained from CIAT and selected through participatory evaluations with farmers. That work had come to a halt after organizational changes in INTA some 10 years ago. A seed multiplication system is now proposed in which INTA and private sector use in vitro multiplication technologies to provide farmer-groups with improved planting material that can be further multiplied to meet farmers' demand. The cassava processing companies are also considered to have a role to play in the cassava seed sector.

\section{Revitalizing Irish Seed Potato Systems in Malawi}

A gender sensitive analysis of a project (2007-2016, Irish Aid funded, CIP coordinated and implemented with multiple partners) that promoted more sustainable potato seed production systems and targeted 4500 smallholder farmers. Factors that contribute to low productivity of potato in Malawi include the use of poor quality planting materials, the use of varieties that are not suitable for their existing end-uses, and limited knowledge of farmers and of extension workers on improving potato production practices. Key achievements from phase 1(2007-2012) included improved production training for more than 200 extension staff and 15,000 farmers (1/3 woman); 13,000 farmers were provided with access to small packs of promotion seed, and 86 diffuse light stores (DLS) were constructed. The analysis showed that women had less access to improved potato technology than men. This calls for more gender sensitive approaches.

\section{Unleashing the Power of Cassava in Africa (UPoCA)}

This multi-country cassava project (2008-2010) was funded by USAID in response to the 2006-2007 food price crisis and was implemented by IITA and covered DR Congo, Ghana, Malawi, Mozambique, Nigeria, Sierra Leone, and Tanzania. It drew on prior research results and aimed to close the yield gap and to encourage value-adding processing by farmers and communities to better access markets. By the end of 2009, smallholder beneficiaries associated with 55 partner organizations and 11 agriculture-related 
firms established 306 community cassava stem multiplication sites and root production farms totaling 10,097 ha with 58 improved varieties. Through experiential learning at 24 hands-on short-term courses, 345 men and 142 women learnt improved techniques in cassava production, processing, product development, and packaging/ labeling. Eight new technologies were introduced to rural communities. The project experienced significant obstacles in getting the planting materials of improved cassava varieties out.

\section{Banana Tissue Culture in Kenya, Uganda, and Burundi}

This program aimed to give small-scale growers access to disease-free planting material of improved drought resistant banana varieties by supporting commercial nurseries at the community level that were linked to tissue culture laboratories. The project was funded by German Technical Cooperation (GTZ) and implemented in Kenya, Uganda and Burundi. It had 6-7 intervention sites per country. The nursery technology and the use of the plantlets by farmers was capital and labour intensive and maintaining the quality standards within TC production and the nurseries was a challenge. The plantlets were predominantly bought by NGO projects to be handed out or sold to farmers. There was no regular demand for TC based banana plantlets, pointing to the importance of advocacy and policy efforts to create demand.

\section{Crop Crisis Control Project (C3P), Banana Seed Systems in the Context of a Disease Pandemic}

C3P was an emergency-intervention funded by USAID, and operated for 24 months (2006-2007) in six countries to mitigate against the effects of banana Xanthomonas Wilt (BXW) in the Great Lakes Region. Its principal focus was to respond to cassava mosaic disease. It was run by a consortium of more than 30 research and development partners with technical backstopping from the International Institute of Tropical Agriculture (IITA) and Bioversity International and with overall management by Catholic Relief Services.). It introduced improved varieties, made available through the use of macro cloning techniques; the lack of clean source material and low multiplication rates hindered the availability of sufficient planting material. Mobilizing collective action was important objective (management of the disease, multiplication and distribution of new planting material). The project trained more than 1,000 extension staff and 65,000 farmers on BXW identification and management (avoiding contamination via tools, the use of clean planting materials, uprooting infected plants and the removal of male buds).

\section{Responding to disease pandemics in Great Lakes Cassava Initiative (GLCI)}

The GLCI (2007-mid 2012) was a Bill \& Melinda Gates Foundation initiative in response to two cassava disease pandemics (cassava mosaic disease -CMD and cassava brown streak disease -CBSD), implemented in six East and Central African countries around the Great Lakes by 50 partners. It was funded by the Bill \& Melinda Gates Foundation, coordinated by Catholic Relief Services (CRS) and the International Institute of Tropical Agriculture (IITA) and managed to reach 1.9 million farmers The program used a decentralized farmer group approach for the multiplication and dissemination of farmer-selected, improved, disease-tolerant, cassava varieties. Thousands of minimally subsidized multiplication sites and hundreds of fully subsidized varietal demonstrations plots were established. There was systematic use of PCR (Polymerase Chain Reaction) to , visual inspection and surveys in multiplication sites to prevent the multiplication and dissemination of diseased materials. Vouchers give farmers free access to 20-25 stems per household (app. 100 cuttings). 
Table 2: Key characteristics of common conventional propagation material of 4 RTB crops and maize (adapted from Andrade et al., 2016)

\begin{tabular}{|c|c|c|c|c|c|c|}
\hline & Maize & Banana & Cassava (2) & Potato & Sweet potato (8) & Yam (9) \\
\hline \begin{tabular}{|l|} 
Consumed \\
plant part
\end{tabular} & seeds & fruits & roots & tubers & roots & tubers \\
\hline \begin{tabular}{|l|} 
Most common \\
propagation \\
material \\
\end{tabular} & seeds & suckers (ariel shoots) & stem cuttings & tubers & vine cuttings & tubers \\
\hline $\begin{array}{l}\text { Multiplication } \\
\text { ratio }\end{array}$ & $70-200$ & $1: 10$ to $1: 20$ suckers & $8-12$ & $6: 15$ tubers $(4)$ & $\begin{array}{l}\text { 3-15 (a vine may yield } 2 \text { or } 3 \\
\text { cuttings 30-cm long) }\end{array}$ & $1: 8$ tubers \\
\hline Bulkiness & \begin{tabular}{|l|}
$15-25$ \\
$\mathrm{~kg} / \mathrm{ha} \mathrm{(1)}$
\end{tabular} & 1000 to $2500 \mathrm{~kg} / \mathrm{ha}$ & $\begin{array}{l}\text { 10,000 three-node stem } \\
\text { cuttings ( } 15 \mathrm{~cm} \text { long) per ha }\end{array}$ & 1000 to $2000 \mathrm{~kg} / \mathrm{ha}$ & \begin{tabular}{|l} 
about $666 \mathrm{~kg}$ depending on \\
variety \& stage of wilting \\
$(33,300$ cuttings of $25-30 \mathrm{~cm})$
\end{tabular} & 10,000 tubers \\
\hline $\begin{array}{l}\text { Storability of } \\
\text { harvested seed }\end{array}$ & $\begin{array}{l}\text { Up to one } \\
\text { year }\end{array}$ & 2 to 3 weeks depending on the season & 2 to 3 weeks maximum & Up to 6 months & A maximum of 2 to 3 days & 3 to 4 months \\
\hline Seed cost $(\$ / h a)$ & $\begin{array}{l}\$ 16 \text { to } \\
\$ 27^{*}\end{array}$ & $\begin{array}{l}\$ 32 \text { to } \$ 2240 \text {, but usually free as } \\
\text { farmers would use their own }\end{array}$ & $\begin{array}{l}\$ 60 \text { to } \$ 120 \text {, but usually free } \\
\text { as taken from own harvest }\end{array}$ & $\begin{array}{l}\text { Up to } 50-70 \% \text { of the total } \\
\text { production cost (3): } \$ 2527 / \text { ha } \\
\text { (Chile, 5); } \$ 818 / \text { ha (Idaho, 6); } \\
\$ 1090 / \text { ha (Peru, 7) }\end{array}$ & $\begin{array}{l}\text { Highly variable. For Tanzania: } \\
\$ 2 \text { bundle of } 300 \text { vines }(900 \\
\text { cuttings),circa } \$ 76 / \text { ha }\end{array}$ & About $\$ 500$ to 800 \\
\hline $\begin{array}{l}\text { Major pests and } \\
\text { diseases carried } \\
\text { over to next } \\
\text { generation via } \\
\text { the planting } \\
\text { material }\end{array}$ & & $\begin{array}{l}\text { Banana bunchy top virus (BBTV), } \\
\text { banana streak virus (BSV), banana } \\
\text { bract mosaic virus (BBrMV); bacterial } \\
\text { wilts caused by Ralstonia spp., and } \\
\text { Xanthomonas sp.; Fusarium wilt; } \\
\text { nematodes (Radopholus similis, } \\
\text { Pratylenchus spp., Helicotylenchus } \\
\text { spp., Meloidogyne spp., Hoplolaimus } \\
\text { spp. and weevils (Cosmopolites } \\
\text { sordidus) }\end{array}$ & $\begin{array}{l}\text { Cassava mosaic viruses } \\
\text { (CMVs), cassava brown } \\
\text { streak viruses (CBSVs), } \\
\text { cassava frogskin-associated } \\
\text { viruses (CFSVs); bacterial } \\
\text { blights (Xanthomonas } \\
\text { campestris pv manihotis); } \\
\text { cassava green mite and } \\
\text { mealy bugs }\end{array}$ & $\begin{array}{l}\text { Potato virus X (PVX), potato } \\
\text { virus Y (PVY), potato leafroll } \\
\text { virus (PLRV), Ralstonia, } \\
\text { Rhizoctonia, Pectobacterium, } \\
\text { Spongospora, Globodera, } \\
\text { Meloidogyne, Tecia, } \\
\text { Symmetrischema, } \\
\text { Phthorimaea, etc. (3) }\end{array}$ & $\begin{array}{l}\text { Sweet potato virus disease: a } \\
\text { complex arising from interaction } \\
\text { between sweet potato chlorotic } \\
\text { stunt virus (SPCSV) and sweet } \\
\text { potato feathery mottle virus } \\
\text { (SPFMV) transmitted by whitefly } \\
\text { and aphids }\end{array}$ & $\begin{array}{l}\text { Viruses: yam mosaic virus } \\
\text { (YMV), yam mild mosaic } \\
\text { virus (YMMV); nematodes: } \\
\text { Scutellonema bradys, } \\
\text { Meloidogyne spp.; fungi: } \\
\text { Botryodiplodia sp., Fusarium } \\
\text { sp.; insects: termites } \\
\text { (Amitermes sp.), tuber moth } \\
\text { (Euzopherodes vapidella), } \\
\text { etc. (10) }\end{array}$ \\
\hline
\end{tabular}

Peru, according to the INIA website www.inia.gob.pe/prod-servicios/semillas

(2) IYA (2014)

(3) Thomas-Sharma et al. (2015)

(4) Struik and Wiersema (1999)

(5) Ministerio de Agricultura (2013). 1 USD = 554 Chilean pesos

(6) Patterson (2014)

(7) Victor Suárez, personal communication. Varieties Canchán and Yungay in Julcán province, La Libertad department in 2013. 1 USD = 2.75 Peruvian Sol.

(8) Kwame Ogero, personal communication

(9) Ibana (2011)

(10) Emehute et al. 1998 